\title{
Report on ticks collected in the Southeast and Mid-West regions of Brazil: analyzing the potential transmission of tick-borne pathogens to man
}

\author{
Relato sobre carrapatos coletados no Sudoeste e no Centro-oeste do Brasil \\ analisando a potencial transmissão de microorganismos de \\ carrapatos para o homem
}

\author{
Luiz Tadeu Moraes Figueiredo', Soraya Jabur Badra', Luiz Eloy Pereira² \\ and Matias Pablo Juan Szabó ${ }^{3}$
}

\begin{abstract}
Specimens of ticks were collected in 1993, 1996, 1997, and 1998, mostly from wild and domestic animals in the Southeast and Mid-West regions of Brazil. Nine species of Amblyommidae were identified: Anocentor nitens, Amblyomma cajennense, Amblyomma ovale, Amblyomma fulvum, Amblyomma striatum, Amblyomma rotundatum, Boophilus microplus, Boophilus annulatus, and Rhipicephalus sanguineus. The potential of these tick species as transmitters of pathogens to man was analyzed. A Flaviviridade Flavivirus was isolated from Amblyomma cajennense specimens collected from a sick capybara (Hydrochaeris hydrochaeris). Amblyomma cajennense is the main transmitter of Rickettsia rickettsii (=R. rickettsi), the causative agent of spotted fever in Brazil. Wild mammals, mainly capybaras and deer, infested by ticks and living in close contact with cattle, horses and dogs, offer the risk of transmission of wild zoonosis to these domestic animals and to man.
\end{abstract}

Key-words: Brazilian ticks. Tick-borne pathogens.

Resumo Foram coletados espécimes de carrapatos em 1993, 1996, 1997, e 1998, principalmente de animais selvagens e domésticos, nas Regiões Sudeste e Centro-oeste do Brasil. Nove espécies de Amblyommidae foram identificadas: Anocentor Nitens, Amblyomma cajennense, Amblyomma ovale, Amblyomma fulvum, Amblyomma striatum, Amblyomma rotundatum, Boophilus microplus, Boophilus annulatus e Rhipicephalus sanguineus. Analisou-se o potencial destas nove espécies de carrapatos como transmissores de patógenos para o homem. Um Flaviviridade Flavivirus foi isolado de espécimes de Amblyomma cajennense coletados de um capivara doente (Hydrochaeris hydrochaeris). Amblyomma cajennense é o transmissor principal da Rickettsia rickettsii (=R. rickettsi), o agente causador da febre maculosa no Brasil. Os mamíferos selvagens, principalmente capivaras e veados infestados por carrapatos vivem em próximo contato com gado, cavalos e cachorros, com quem compartilham os mesmos carrapatos, oferecendo risco de transmissão destas zoonoses silvestres aos animais domésticos e ao homem.

Palavras-chaves: Carrapatos brasileiros. Patógenos transmitidos por carrapatos.

\footnotetext{
1. Unidade Multidepartamental de Pesquisa em Virologia, Faculdade de Medicina de Ribeirão Preto, Universidade de São Paulo, Ribeirão Preto, SP; 2. Instituto Adolfo Lutz de São Paulo, São Paulo, SP; 3. Departamento de Patologia Veterinária, Faculdade de Ciências Agrárias e Veterinárias de Jaboticabal, Universidade Estadual Paulista, Jaboticabal, SP.

Financial support: São Paulo State Government Research Agency (FAPESP).

Address to: Prof. Luiz Tadeu M. Figueiredo. Unidade Multidepartamental de Pesquisa em Virologia/FMRP/USP. Av. Bandeirantes 3900 , 14049-900 Ribeirão Preto, SP, Brazil.

Tel: 5516 633-0436, Fax: 5516 633-6695.

E-Mail: Itmfigue@fmrp.usp.br

Recebido para publicação em 21/12/98.
} 
Ticks (Arthropoda, Chelicerata, Acarida, Anactinotrichoida, Ixodida) are cosmopolitan hematophagous parasites belonging to the families Nuttalliellidae, Argasidae, Ixodidae and Amblyommidae ${ }^{711}$. Ticks have wide-ranging effects on the health of animals and humans. They cause disease in domestic animals by direct spoliation, by inoculation of toxins and by transmitting microorganisms ${ }^{13}$. Transmission of tick-borne microorganisms to humans occurs accidentally by biting ${ }^{21}$. Although ticks in Brazil can transmit other human infectious diseases, two known human diseases transmitted by ticks in Brazil are spotted fever (Rickettsia rickettsii) ${ }^{24}$, and Lyme disease (Borrelia burgdorferr) ${ }^{26}$.

The purpose of this paper is to report on specimens of ticks collected in the Southeast and Mid-West regions of Brazil as part of a study on arboviruses and other tick-borne microorganisms, through analyzing the potential of these arthropods as transmitters of pathogens to man.

\section{MATERIAL AND METHODS}

Tick collections were carried out in the Southeast (State of São Paulo, SP, and State of Minas Gerais, MG) and Mid-West regions (State of Mato Grosso do Sul, MS) of Brazil, as shown in Figure 1.

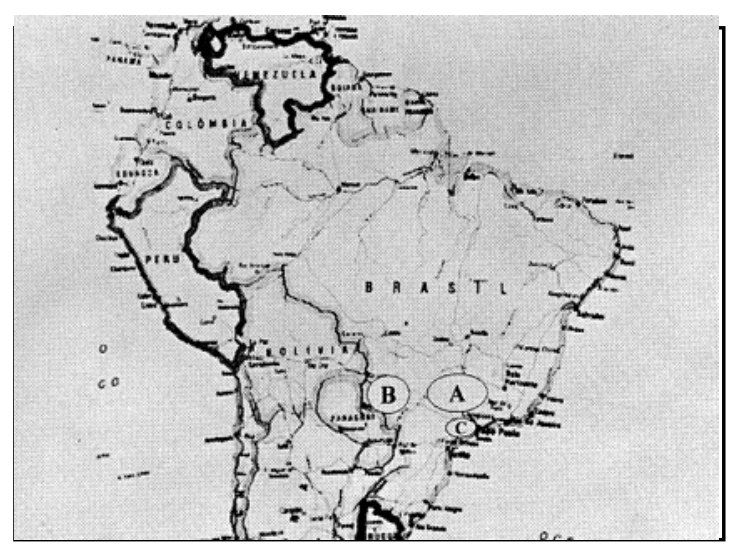

Figure 1 - Map of Brazil showing the areas of tick collection. A-Western plateau of the States of São Paulo and Minas Gerais. B-Pantanal in the State of Mato Grosso do Sul. C-Serra do Mar Region in the State of São Paulo.

In the Southeast region of Brazil, most of the ticks were collected in the Western plateau of SP and MG (Figure $1 \mathrm{~A}$ ). This region, with the city of Ribeirão Preto ( $\left.21^{\circ} 11^{\prime} \mathrm{S}, 47^{\circ} 49^{\prime} \mathrm{W}\right)$ as a reference point, belongs to the Parana River mesozoic basin, and is characterized by sierras of $400-1000 \mathrm{~m}$ in altitude and many valleys. The climate of this region is tropical, hot and humid, with a dry winter season, mean temperature of $21.7^{\circ} \mathrm{C}$, and pluviometric index of $1433 \mathrm{~mm}$. The region has tropical forest and extense areas of woody pastures (cerrado). This area is extensively deforested for sugar cane and cattle farms. Forested areas remain, mostly as patches of gallery forest along river borders. Ticks were also collected in the Serra do Mar region in
$\mathrm{SP}$, located at $24^{\circ} \mathrm{S}, 48^{\circ} \mathrm{W}$, a mountain range of about $800 \mathrm{~m}$ in altitude that parallels the coast receding several kilometers and forming plains bounded by the mountains and the ocean. This region therefore includes the mountain, the coast plain and also the border of the Western plateau of SP. The Serra do Mar region is partially covered by a rain forest with $3000 \mathrm{~mm}$ of rainfall and $21^{\circ} \mathrm{C}$ mean temperature (Figure $1 \mathrm{C}$ ). The third region where ticks were collected was the Pantanal of MS (Figure 1B). This is a large seasonal floodplain covering about $140,000 \mathrm{~km}^{1}$ located near the geographical center of South America (19. $4^{\prime}$ 'S, $56^{\circ} 48^{\prime} \mathrm{W}$ ) at approximately $100 \mathrm{~m}$ in altitude. The region is drained to the West by tributaries of the Paraguay River, which flows Southward along the Pantanal Western border. Weather conditions are markedly seasonal; summers (October to March) are hot and humid while winters (April to September) are warm and dry, except for occasional cold fronts from the South.

Ticks were collected in 1993, 1996, 1997, and 1998. Most of the collections were done manually from captured wild and domestic animals. Other collections were carried out directly from the ground and by pulling a cloth drag across vegetation in areas of open grasslands close to patches of gallery forest.

The identification of tick species was determined by the Virus Research Unit of the School of Medicine of Ribeirão Preto, University of São Paulo, in Ribeirão Preto, SP, Brazil.

The taxonomic identification of ticks was done under a Stereomicroscope (Zeiss, Germany), 16-40 times magnification, by comparison with characteristics presented in taxonomic keys ${ }^{4569141516192022}$. Live ticks of the same species collected from the same animal were pooled for virus isolation assays. Other specimens were selected for a tick reference collection and were kept in $70 \%$ ethanol. 


\section{RESULTS}

Forty-four tick collections were made in many localities of the Western plateau of SP and MG, Serra do Mar region, and Pantanal of MS, as shown in Figure 1 and Table 1. The collections were made directly from 1 human (number 1), 5 wild birds (N 2, 8, 14, 22 and 23), 1 amphibian (N 36), 13 wild mammals including coati (Nasua nasua), giant anteater (Myrmecophaga tridactyla), common opossum (Didelphis marsupialis), capybaras (Hydrochaeris hydrochaeris), deer (Blastocerus dichotomus) and rodents (N 3, 5, 9, $11,15,16,17,18,19,27,31,38$ and 44$)$, and 21 domestic animals including dogs, horses and bovine cattle (N 6, 7, 13, 20, 21, 24, 25, 26, 28, $29,30,32,33,34,35,37,39,40,41,42$ and 43 ). Ticks were also collected directly from the ground in 1 case (N 4) or by pulling the cloth drag across vegetation in 2 cases ( $\mathrm{N} 10$ and 12).

As shown in Table 1, about 700 specimens of ticks in different stages were analyzed. The identification of all the adults at the species level was possible, except for 3 female animals (N 5), which were identified at the genus level, Ixodes $\mathrm{sp}$. Nine species of Amblyommidae were identified: Anocentor nitens, Amblyomma cajennense, Amblyomma ovale, Amblyomma fulvum, Amblyomma striatum, Amblyomma rotundatum, Boophilus microplus, Boophilus annulatus, and Rhipicephalus sanguineus. The tick larvae and nymphs, mostly collected by pulling the cloth drag across vegetation, were identified at the family level (Amblyommidae) or genera (Boophilus and Amblyomma).

In the Western plateau of SP and at MG (Figure $1 \mathrm{~A}$ ) the following species of ticks were found, Amblyomma cajennense, Amblyomma ovale, Amblyomma rotundatum, Anocentor nitens, Boophilus annulatus, Boophilus microplus, and Rhipicephalus sanguineus. The tick species found in the Serra do Mar region (Figure 1C) were Amblyomma striatum and Anocentor nitens. The ticks Amblyomma cajennense, and Boophilus microplus were found in the Pantanal region (Figure 1B).

\section{DISCUSSION}

All the tick species observed in this study were previously described in South and Central America ${ }^{4}{ }^{17}$. The same species of ticks, Anocentor nitens, Amblyomma cajennense, Amblyomma rotundatum, Rhipicephalus sanguineus, and Boophilus microplus, were previously observed in a study done in Central Brazil in $1991^{17}$.

In our study, Amblyomma cajennense specimens were collected from horses (Ribeirão Preto), cattle (Patrocínio Paulista, Jaboticabal), dog (Altinópolis), and capybaras (Matão and lbitinga), all in the Western plateau of SP. Specimens of both sexes were also collected from a coati in the Pantanal region. The Amblyomma cajennensecan be found in the Americas, attacking a large number of wild mammal hosts such as Brazilian tapir ( Tapirus terrestris), giant anteater (Myrmecophaga tridactyla) and coati (Nasua nasua). Domestic mammal hosts such as horses, cattle, sheep (Ovis aries), goats (Capra hircus), dogs (Canis familiaris) and pigs (Sus scrofa domestica) are also parasitized ${ }^{22}$.

In Brazil, Amblyomma cajennense is the main transmitter of Rickettsia rickettsii (= R. rickettsi), which is the causative agent of spotted fever. This disease leads to a clinical spectrum ranging from asymptomatic cases to a severe disease with acute febrile presentation, headache, prostration, myalgias, mental confusion, and suggestive exanthema. This disease lasts about 2 to 3 weeks, having necrotic vasculitis as a common complication. The spotted fever is endemic in $\mathrm{SP}$ and $\mathrm{MG}^{1824}$.

A Flaviviridade Flavivirus was isolated from Amblyomma cajennense specimens collected from a sick capybara from Matão (Table 1, N27). An ongoing study includes a more extensive analysis of this new virus. The isolation of other viruses (orbiviruses) from Amblyomma cajennense has been reported in Jamaica ${ }^{8}$.

Capybaras (Hydrochaeris hydrochaeris) are the largest rodents of the world and may live in patches of gallery forest along river borders in close contact with farms, which are usually invaded by these animals for feeding on grain plantations. The capybara can be the reservoir of wild zoonosis in lands almost completely deforested, as is the case of SP. Capybaras living close to the farms and even cities could favor the transference of their ectoparasites to domestic animals, expanding zoonosis and offering risk to man. Besides, these ticks could maintain focal zoonosis for many years due to their longevity off host and reinfestation of hosts, in the same place, for long periods of time ${ }^{128}$. 


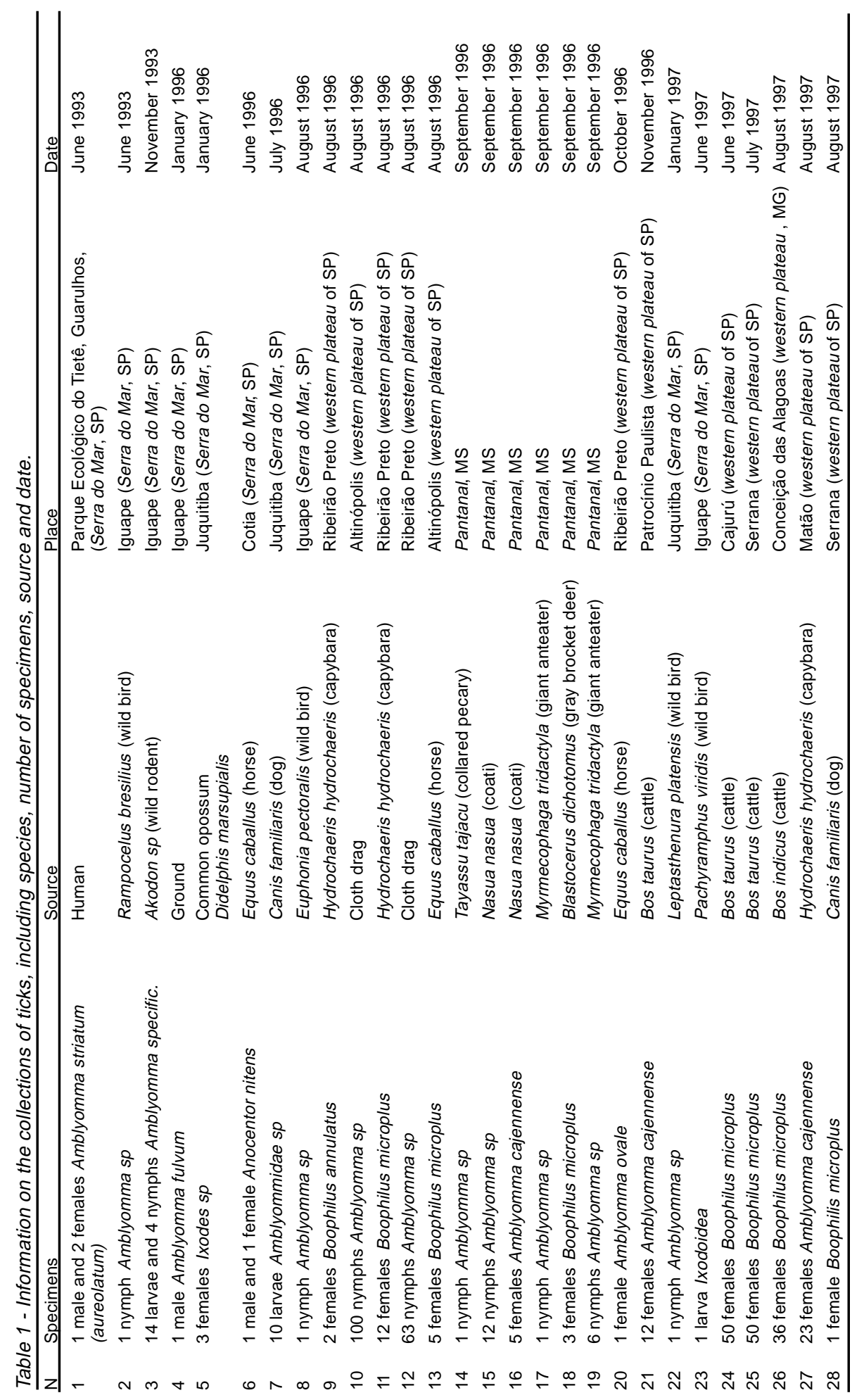


One male Amblyomma fulvum was collected directly from the soil in Iguape, Serra do Mar region, close to the rain forest, in January 1996. This South American tick is described as a wild rodent parasite and it is also a parasite of the giant anaconda 151622 . There is no description of Amblyomma fulvum as a vector of microorganisms infecting man.

One Amblyomma ovale specimen was collected from a horse close to the city of Ribeirão Preto, on the Western plateau of SP, in October 1996. This tick has been described in Brazil as a wild living tick. It has been found infesting Tapirus terrestris (anta) and Panthera onca (jaguar). Larvae and nymphs of these tick probably parasite rodents ${ }^{4522}$. We have no explanation for the finding of this tick in the suburban area of a large city. Amblyomma ovale is also vector of spotted fever group Rickettsia in Brazil.

Three large Amblyomma rotundatum females were obtained from a toad (Bufo marinus) from Guatapará, on the Western plateau of SP, in October $1997^{422}$. There is no description of this tick as vector of microorganisms infecting man.

Amblyomma striatum, one male and 2 females, were collected from a tick collector working in the Tietê Park in Guarulhos County, close to São Paulo City, Serra do Mar region, in June 1993. Amblyomma striatum is a parasite of wild mammals and domestic animals such as dogs living close to cities $^{4} 5$ 22. Rickettsia rickettsii (=R. rickettsi), the causative agent of spotted fever, has been described infecting Amblyomma striatum in Central and South America, including Brazil ${ }^{21}$.

Anocentor nitens specimens were obtained from horses in the Serra do Mar region (Cotia, Figure 1C). The same species was collected from horses in the Western plateau of SP (Uchoa, Figure 1A). Anocentor nitens are found in all the Americas as horse parasites, mainly in the ears. The inflammatory process produced by the tick predisposes horses to secondary bacterial infections and collapse of their ears ${ }^{620}$. Anocentor nitens was also collected from wild animals such as capybaras (Hydrochaeris hydrochaeris) ${ }^{14}$. This tick is the vector of Babesia caballi, a malarialike protozoa that parasites erythrocytes and causes babesiosis in horses. Rodents are known as the reservoirs of babesiosis ${ }^{21}$. It is not known whether this tick can transmit Babesia microti, the causative agent of human babesiosis.

Two female Boophilus annulatus were collected from capybara (Hydrochaeris hydrochaeris) from Ribeirão Preto, Western plateau of SP, in August of 1996. This tick is known as a vector of Babesia bigemina, the pathogen of Texas cattle fever ${ }^{121}$

Many specimens of Boophilus microplus were collected from capybaras in Ribeirão Preto, deer (Blastocerus dichotomus) from Presidente Epitácio, horses from Altinópolis, a dog in Serrana and cattle (Bos taurus and Bos indicus) in the localities of Cajurú, Conceição das Alagoas, São Sebastião do Paraiso, Jacuí and Jaboticabal in the Western plateau of SP and MG. Boophilus microplus were also collected from deer (Blastocerus dichotomus), and coati (Nasua nasua). This tick can be found in South and Central America, Australia, Africa and Taiwan. It is mostly a cattle ectoparasite. However, it can also be found in horses, sheep (Ovis aries), goats (Capra hircus), and wild mammals ${ }^{14}$. Boophilus microplus produces massive infestations, spoiling nutrients and causing anemia as well as malnutrition in animals. This tick is also the primary vector of babesiosis in cattle, caused by Babesia bigemina, and anaplasmosis, caused by the intracellular bacteria Anaplasma marginale that infect a variety of wild and domestic ungulates ${ }^{21}$.

Specimens of Rhipicephalus sanguineuswere collected from dogs in Jaboticabal and in Cravinhos on the Western plateau of SP. This tick is a cosmopolitan dog ectoparasite ${ }^{1}$. Rhipicephalus sanguineus is recognized as an important transmitter of microorganisms from dog to man, such as Rickettsia rhipicephali, the causative of spotted fever, and Rickettsia conorii, the causative of boutonneuse fever ${ }^{12}$. It is also the vector of Ehrlichia canis that causes ehrlichiosis in domestic mammals ${ }^{27}$. Arboviruses such as the Reoviridae Orbivirus Wad Medani, and the Bunyaviridae Nairovirus Thogoto and Dera Ghazi Khan were isolated from Rhipicephalus sanguineus ${ }^{3} 1021$.

Lyme disease, caused by the spirochete Borrelia burgdorferi, has been described in Brazil since $1990^{26}$. There is no report of isolation of Borrelia burgdorferi in Brazil and the cases were confirmed by serologic methods. The infection can produce fever, headache, malaise, skin erythema migrans, multiple annular lesions and lymphadenopathy as early clinical manifestations. Arthritis and chronic neurologic manifestations can start months to years after the acute disease. About $95 \%$ of 24 cases of Lyme disease studied in Brazil lived or visited forested areas probably inhabited by small wild mammals. Some of the 
Lyme-disease patients used to ride horses and others played with dogs infested by ticks. The ticks Ixodes loricatus, Ixodes didelphidis, Amblyomma cajennense, Amblyomma aureolatum and Rhipicephalus sanguineus were captured from marsupials and rodents living in a locality where there occurred human cases of Lyme disease. However, infection by Borrelia was not investigated in these ticks ${ }^{26}$.

Relapsing fever caused by spirochetes of the genus Borrelia 2325 , and ehrlichiosis caused by the bacteria Ehrlichia chafeensis, could be also transmitted by ticks in $\mathrm{Brazil}^{27}$. It is also probable that tick arboviruses can cause human disease in Brazil.

The variety of species found in our study, which include specimens collected in an extensive area of Brazil and from a large variety of wild and domestic animals, shows the vital importance of this parasite. Tick species collected in our study, such as Anocentor nitens, Amblyomma cajennense, Rhipicephalus sanguineus, and Boophilus microplus, are known to disseminate parasites in domestic animals of the Southeast and MidWest regions of Brazil ${ }^{4517}$. These ticks are known transmitters of microorganisms including protozoa, bacteria and viruses, and offer risk to man due to the close contact with domestic animals. Wild mammals, mainly capybaras and deer, infested by ticks and living in close contact with cattle, horses and dogs, offer the risk of transmission of wild zoonosis to these domestic animals and to man. Further studies on tick microorganism infections, tick density or seasonal activity, carried out in different areas of the country, are necessary in order to better elucidate the importance of human tick-borne diseases in Brazil.

\section{ACKNOWLEDGEMENTS}

We are grateful to Dr. Jean Louis Camicas of the Laboratoire Epidémiologie des Maladies à Vecteurs of ORSTOM (L'Institut français de recherche scientifique pour le dévéloppement en coopération), Montpellier, France, for help on tick taxonomy. We are also grateful to Dr.Roy Larson and Dr. Robert Shope for review of the manuscript.

\section{REFERENCES}

1. Aeschlimann A. Ticks and disease: susceptible hosts, reservoir hosts and vectors. In:Toft CA, Aeschlimann A, Bolis L (eds) Parasite-host associations: resistance or conflict? Oxford University Press, London, p. 148-156, 1991.

2. Aeschlimann A, Morel PC. Boophilus geigyi n.sp. (Acarina: Ixodoidea) une nouvelle tique du bétail de I'Ouest Africain. Acta Tropica 22: 161-168, 1965.

3. American Committee on Arthropod-borne Viruses. International catalogue of arboviruses including certain other viruses of vertebrates. $3^{\text {th }}$ edition. The American Society of Tropical Medicine and Hygiene, San Antonio, Texas, 1985.

4. Aragão R, Fonseca F. Notas de Ixodologia. VIII. Lista e chave para os representantes da fauna ixodológica brasileira. Memórias do Instituto Oswaldo Cruz 59:115129, 1961.

5. Aragão R, Fonseca F. Notas de Ixodologia. IX. O complexo Ovale do gênero Amblyomma. Memórias do Instituto Oswaldo Cruz 59: 131-147, 1961.

6. Arthur DR. Ticks, a monograph of the Ixodoidea. Part V on the genera Dermacentor, Anocentor, Cosmiomma, Boophilus \& Margaropus. University Press, Cambridge, 1960

7. Camicas J-L, Morel PC. Position Systématique et classification des tiques (Acarida: Ixodida). Acarologia 28:410-420, 1977.
8. Casals J. Antigenic properties of tickborne viruses: present state and knowledge. Miscellaneous Publications of the Entomological Society of America 7:327-329, 1970.

9. Clifford CM, Anastos G. The use of chaetotaxy in the identification of larval ticks (Acarina: Ixodidae). Jounal of Parasitology 46:567-578, 1960.

10. Dumler JS, Bakken JS. Human ehrlichioses: newly recognized infections transmitted by ticks. Annual Review of Medicine 49:201-213, 1998.

11. Evans GO. Principles of Acarology. CAB International, Wallingford. 220 p, 1992.

12. Freitas MG, Costa HMA, Costa JO, lide P. Família Ixodidae. In: Entomologia e acarologia médica e veterinária. $6^{\text {th }}$ edition. Precis Editora Gráfica, Belo Horizonte, p.35-52, 1982.

13. Food and Agriculture Organization (FAO) - Yearbook Production, 1994 (Vol 48), Rome, 1995.

14. Jones EK, Clifford CM, Keirans JE, Kohls GM. The ticks of Venezuela (Acarina: Ixodoidea) with a key to the species of Amblyomma in the western hemisphere. Brigham Young University Science Bulletin, Biological Series 19:1-40, 1972.

15. Keirans JE. Redescription of Amblyomma fulvum Neumann 1899 (Acarina: Ixodidae), a parasite of the giant anaconda in Northern South America. Jounal of Medical Entomology 2:138-139, 1972. 
16. Keirans JE, Clifford CM . The genus Ixodes in the United States: a scanning electron microscope study and key to the adults. Journal of Medical Entomology 2(suppl):1-49, 1978

17. Knight JC. Observations on potential tick vectors of human disease in the cerrado region of Central Brazil. Revista da Sociedade Brasileira de Medicina Tropical 25:145-146, 1992.

18. Lemos ERS, Machado RD, Coura JR, Guimarães MAA, Freire NMS, Amorim M, Gazeta GS. Epidemiological aspects of the Brazilian spotted fever: seasonal activity of ticks collected in an endemic area in São Paulo, Brazil. Revista da Sociedade Brasileira de Medicina Tropical 30:181-185, 1997.

19. Mendez Arocha M, Ortiz I. Revisión de las garrapatas venezolanas del género Ixodes Latreille, 1795 y estudio de un nuevo Amblyomma (Acarina: Ixodidae). Memoria de la Sociedad de Ciencias Naturales La Salle, Caracas, Venezuela 18:196-208, 1958.

20. Nuttall GHF, Warburton C, Robinson LE. Ticks - A monograph of the Ixodoidea, Part IV - The genus Amblyomma. Cambridge University, London, 1926.

21. Piesman J, Gage KL. Ticks and mites and the agents they transmit. In: Beaty BJ, Marquardt WC (eds) The biology of disease vectors. University Press of Colorado, Denver, p160-174, 1996.

22. Robinson LE. The genus Amblyomma. University Press, Cambridge, 1926.
23. Steere AC. Borrelia burgdoferi (Lyme disease, Lyme borreliosis). In: Mandell GL, Bennett J, Dolin R (eds) Principles and practice of infectious diseases. $4^{\text {th }}$ edition. Churchill Livingstone, New York, p. 2143-2155, 1995.

24. Tiriba AC. Rickettsioses. In: Veronese R, Foccacia R (eds) Tratado de Infectologia. Atheneu, São Paulo, p. 527-532, 1996.

25. Trevejo RT, Schriefer ME, Gage KL, Safraneck TJ, Orloski KA, Pape WJ, Montenieri JA, Campbell GL. An interstate outbreak of tick-borne relapsing fever among vacationers at a Rocky Mountain cabin. American Journal of Tropical Medicine and Hygiene 58:743-747, 1998.

26. Veronesi R, Philipp MT, Yoshinari NH, Roberts D, Franco BN. Doença de Lyme. In: Veronese R, Foccacia R (eds) Tratado de Infectologia. Atheneu, São Paulo, p. 972-984, 1996.

27. Walker DH, Raoult D. Rickettsia Rickettsii and other spotted fever group rickettsiae (rocky mountain spotted fever and other spotted fevers). In: Mandell GL, Bennett $\mathrm{J}$, Dolin R (eds) Principles and practice of infectious diseases. $4^{\text {th }}$ edition. Churchill Livingstone New York, p.1721-1735, 1995.

28. Woodring JL, Higgs S, Beaty BJ. Natural cycles of vectorborne pathogens. In: Beaty BJ, Marquardt WC (eds) The biology of disease vectors. University Press of Colorado, Denver, p. 51-72, 1996. 